\title{
Intrapulmonary shunting in the biliary atresia/polysplenia syndrome: reversal after liver transplantation
}

M S Fewtrell, G Noble-Jamieson, S Revell, J Valente, P Friend, P Johnston, A Rasmussen, N Jamieson, R Y Calne, N D Barnes

\begin{abstract}
One hundred and seventy three children, including 93 with biliary atresia, received liver grafts at Addenbrooke's Hospital between 1983 and 1993. Of these, only seven developed cyanosis due to intrapulmonary shunting as a complication of their liver disease, and all seven of these had the biliary atresia/polysplenia syndrome. Intrapulmonary shunting was confirmed by a radioisotope scan in four children. Only one child with the syndrome did not have cyanosis when undergoing transplantation. Seven of the eight children are alive 6-54 months after transplantation, with normal pulmonary and hepatic function. Cyanosis recurred in one child who developed chronic rejection with liver failure. In conclusion: (a) there is a strong association between the biliary atresia/polysplenia syndrome and cyanosis due to intrapulmonary shunting; (b) intrapulmonary shunting is fully reversible after successful liver transplantation; and (c) cyanosis, once present, is progressive, and these children should be considered for liver transplantation as soon as it occurs.
\end{abstract}

(Arch Dis Child 1994; 70: 501-504)

The association of hypoxaemia with chronic liver disease is rare in childhood but well recognised in adults following the original description in 1884 by Fluckiger. ${ }^{1}$ Resolution of cyanosis after recovery from hepatic encephalopathy, fulminant liver failure, and in cirrhosis during periods of improved liver function has been reported. ${ }^{2} 3$ Cyanosis has been regarded as a contraindication to orthotopic liver transplantation, ${ }^{4}$ though resolution after successful transplantation was described by Starzl $e t a^{5}$ as early as 1968 . More recently, there have been other reports of resolution of cyanosis in patients transplanted for $\alpha_{1}$ antitrypsin deficiency, ${ }^{6}$ primary biliary cirrhosis, ${ }^{7}$ and biliary atresia. ${ }^{8}$

Among children with biliary atresia about $25 \%$ have associated anatomical abnormalities. In the Addenbrooke's series of 173 children receiving liver transplants, 93 had biliary atresia and eight of these had the biliary atresia/polysplenia syndrome. Only seven children in the whole series were cyanosed and these all had the biliary atresia/polysplenia syndrome. This association has not previously been described. We report our experience of liver transplantation in children with this syndrome.

\section{Subjects and methods}

Eight children, three boys and five girls, with the biliary atresia/polysplenia syndrome received liver grafts between 1989 and 1993. Seven also had abdominal situs inversus. All eight had an anomalous inferior vena cava (left sided in two and interrupted in six). Two had ostium secundum atrial septal defects and one a perimembranous ventricular septal defect which had closed spontaneously by the time of transplantation. None had external dysmorphic features and all were intellectually and developmentally normal.

All the children had portoenterostomy operations between 7 and 12 weeks of age, but went on to develop cirrhosis. The onset of cyanosis occurred between 9 months and 9 years of age, and was not obviously correlated with the degree of liver dysfunction at the time. Desaturation was confirmed by arterial blood gas measurement or oxygen saturation monitoring, or both, and four children had the shunt measured by an isotopic lung perfusion scan using technetium labelled macroaggregated albumin ( ${ }^{99 \mathrm{~m}} \mathrm{Tc}-\mathrm{MAA}$ ) (table). Intracardiac right to left shunting was excluded in all patients by echocardiography, and by cardiac catheterisation in four. Three children had pulmonary angiography which confirmed the presence of intrapulmonary shunting.

Cyanosis, once present, was progressive. Serial lung perfusion scans performed in three children showed a gradual increase in the shunt before transplantation. Four patients required supplementary oxygen, and in two cyanosis was the main reason for entry to the waiting list.

One child required artificial ventilation preoperatively for increasing hypoxaemia associated with sepsis. Other symptoms of hepatic dysfunction were generally not severe, apart from patient 5 , in whom there was a sudden deterioration of liver function necessitating emergency transplantation. Transplantation was technically. difficult in these children because of their complicated anatomy and small size in patients 1 and 7, and intraoperative blood losses were high (range $34-2320 \mathrm{ml} / \mathrm{kg}$, median $107 \mathrm{ml} / \mathrm{kg}$ ). Two children required early retransplantation, one for primary non-function at two days and one for hepatic artery thrombosis at one week. 


\begin{tabular}{|c|c|c|c|c|c|c|c|c|c|c|}
\hline \multirow[b]{2}{*}{$\begin{array}{l}\text { Patient } \\
\text { No }\end{array}$} & \multirow{2}{*}{$\begin{array}{l}\text { Age at } \\
\text { onset of } \\
\text { cyanosis } \\
\text { (years) }\end{array}$} & \multirow{2}{*}{$\begin{array}{l}\text { Oxygen } \\
\text { saturation/ } \\
\mathrm{PaO}_{2} \\
\text { in air } \\
(\mathrm{mm} \mathrm{Hg})\end{array}$} & \multicolumn{2}{|c|}{$\begin{array}{l}{ }^{99 \mathrm{~m}} T c-M A A \text { lung } \\
\text { perfusion scan }\end{array}$} & \multirow[b]{2}{*}{$\begin{array}{l}\text { Age at } \\
\text { transplantation } \\
\text { (years) }\end{array}$} & \multirow{2}{*}{$\begin{array}{l}\text { Duration of } \\
\text { postoperative } \\
\text { ventilation } \\
\text { (days) }\end{array}$} & \multirow{2}{*}{$\begin{array}{l}\text { Duration of } \\
\text { postoperative } \\
\text { oxygen } \\
\text { supplementation }\end{array}$} & \multicolumn{2}{|c|}{$\begin{array}{l}\text { Postoperative shunt } \\
\left({ }^{99 \mathrm{~m}} \mathrm{Tc}-M A A\right)\end{array}$} & \multirow{2}{*}{$\begin{array}{l}\text { Outcomel } \\
\text { time since } \\
\text { transplantation } \\
\text { (years) }\end{array}$} \\
\hline & & & $\begin{array}{l}\text { Time before } \\
\text { transplantation }\end{array}$ & $\begin{array}{l}\text { Shunt } \\
(\%)\end{array}$ & & & & $\begin{array}{l}\text { Time since } \\
\text { transplantation } \\
\text { (weeks) }\end{array}$ & $\begin{array}{l}\text { Shunt } \\
\text { (\%) }\end{array}$ & \\
\hline 1 & $\begin{array}{l}\text { Not seen } \\
9 \cdot 0\end{array}$ & $\begin{array}{l}-172 \\
86 /-\end{array}$ & - & $\begin{array}{l}- \\
-\end{array}$ & $\begin{array}{c}0.5 \\
11 \cdot 0 \dagger\end{array}$ & $\begin{array}{l}2 \\
1 \cdot 5\end{array}$ & $\begin{array}{l}36 \text { Hours } \\
30 \text { Days }\end{array}$ & $\begin{array}{r}- \\
3 \\
12\end{array}$ & $\begin{array}{l}-\overline{7} \\
6.5\end{array}$ & $\begin{array}{l}\text { Alive/3 } \\
\text { Alive/3 }\end{array}$ \\
\hline $\begin{array}{l}3 \\
4\end{array}$ & $\begin{array}{l}8 \cdot 5 \\
0 \cdot 92\end{array}$ & $\begin{array}{l}-160 \cdot 3 \\
-142 \cdot 2\end{array}$ & $\begin{array}{l}\overline{9} \text { Months } \\
3 \text { Months }\end{array}$ & $\begin{array}{r}-\overline{23} \\
49\end{array}$ & $\begin{array}{l}9 \cdot 2 \\
2 \cdot 5\end{array}$ & $\begin{array}{r}2 \\
21\end{array}$ & $\begin{array}{l}25 \text { Days } \\
30 \text { Days }\end{array}$ & $\overline{4}$ & $\overline{2} \cdot 7$ & $\begin{array}{l}\text { Alive } / 4 \cdot 6 \\
\text { Alive } / 1 \cdot 2\end{array}$ \\
\hline 5 & $1 \cdot 3$ & $80 /-$ & $\begin{array}{l}14 \text { Months } \\
2 \text { Months } \\
1 \text { Month }\end{array}$ & $\begin{array}{l}22 \\
45 \cdot 6 \\
55 \cdot 7\end{array}$ & $2 \cdot 5$ & 48 & 15 Weeks & $\begin{array}{r}8 \\
13 \\
32\end{array}$ & $\begin{array}{r}72 \\
29 \\
6\end{array}$ & Alive/ 1.5 \\
\hline 6 & $9 \cdot 2$ & $80 /-$ & $\begin{array}{l}3 \text { Months } \\
3 \text { Weeks }\end{array}$ & $\begin{array}{l}J 3 \cdot \% \\
13 \cdot 6 \\
15\end{array}$ & $9 \cdot 8$ & 2 & 2 Weeks & $\begin{array}{r}22 \\
1 \\
8 \\
20\end{array}$ & $\begin{array}{l}0 \\
16 \cdot 9 \\
12 \\
2\end{array}$ & Alive/0.75 \\
\hline $\begin{array}{l}7 \\
89\end{array}$ & $\begin{array}{l}0.75 \\
2 \cdot 9\end{array}$ & $\begin{array}{l}85 /- \\
82 /-\end{array}$ & 1 Month & $\begin{array}{r}29 \\
-\end{array}$ & $\begin{array}{r}0.92 \ddagger \\
\text { (1) } 3.5 \\
\text { (2) } 4.5\end{array}$ & $\begin{array}{l}30 \\
1 \text { st } 11\end{array}$ & $\begin{array}{l}8 \text { Weeks } \\
6 \text { Months } \\
\text { Died two days }\end{array}$ & $\begin{array}{l}16 \\
- \\
\text { toperatively }\end{array}$ & $\begin{array}{l}2 \\
-\end{array}$ & $\begin{array}{l}\text { Alive/0.75 } \\
\text { Died }\end{array}$ \\
\hline
\end{tabular}

$\star 99 \mathrm{~m}$ Tc-MAA lung perfusion scan: normal value $<6 \%$.

tEmergency retransplantation for hepatic artery thrombosis on day 7 .

$\ddagger$ Emergency retransplantation for primary non-function on day 2 .

Retransplantation for chronic rejection with hepatic encephalopathy and hepatorenal syndrome. $\mathrm{PaO}_{2}=$ arterial oxygen tension.

The duration of postoperative ventilation ranged from one to 48 days; the two children who required prolonged ventilation were the most ill preoperatively and had the largest intrapulmonary shunts. All surviving children were breathing normally in air by four months after the operation and had good graft function by that time. Five children had serial lung perfusion scans which showed a progressive decrease in measured shunt. Transient abnormalities of liver function - for example, associated with episodes of acute rejection or hepatitis - were not clearly associated with an increased oxygen requirement. The child who died (patient 8 ) was the only one with normal abdominal situs. She never gained completely normal liver function after transplantation and developed chronic rejection three months after the operation. Her oxygen requirement decreased after the first operation, but increased again as her liver function deteriorated. She developed hepatorenal syndrome and encephalopathy, requiring emergency retransplantation one year after her first operation, but she died two days later.

\section{Discussion}

The association of chronic liver disease with central cyanosis is well described and has been termed the hepatopulmonary syndrome. ${ }^{9}$ A mild degree of desaturation occurs in up to one third of cirrhotic adults, but clinically significant hypoxaemia is less common.

The pathophysiology of the disorder has been extensively debated. Early workers suggested a rightward shift of the oxyhaemoglobin dissociation curve due to increased levels of 2,3-diphosphoglycerate in cirrhosis as a major aetiological factor, ${ }^{10}$ but subsequent studies showed that the degree of shift is insufficient to produce the hypoxaemia often observed. Another hypothesis was that cyanosis resulted from shunting through abnormal portopulmonary vessels. ${ }^{11}$ These have been demonstrated, during life and at necropsy, but it is impossible for such shunts to result in significant cyanosis given the relatively high oxygen saturation of portal venous blood and the proportion of cardiac output flowing through the abnormal vessels.

More recently, attention has focused on intrapulmonary shunting as the major cause of the hepatopulmonary syndrome, and it is likely that this occurs by at least two mechanisms. Firstly, there is vasodilation of the precapillary vessels and the capillary beds adjacent to the alveoli, ${ }^{12}$ resulting in a diffusion-perfusion defect, as oxygen has to diffuse further into the dilated vessels to produce a given degree of saturation. ${ }^{1314}$ In addition, the increased cardiac output associated with the hepatopulmonary syndrome compounds the situation as the blood has less time in contact with the alveolus. This type of shunt will improve with supplementary oxygen, which increases the diffusion gradient. Secondly, there is a 'true' right to left shunt between pulmonary arterioles and venules, bypassing the alveolus completely, ${ }^{12}$ on which supplementary oxygen will have no effect. Both types of abnormality have been demonstrated in vivo and at necropsy, though their relative importance is unclear. It is possible that the balance varies between patients, and this may account for the variable response to oxygen.

The shunt can be measured simply and accurately using ${ }^{99 m}$ Tc-MAA injected intravenously. ${ }^{131516}$ Normal pulmonary capillaries are 8-15 $\mu \mathrm{m}$ in diameter and trap most of the labelled particles, but $3-5 \%$ pass through the lungs to lodge in end capillaries in the spleen, kidneys, and brain. In the hepatopulmonary syndrome the capillaries are significantly dilated so the proportion of labelled particles passing through the lungs is increased and can be measured. The hepatopulmonary syndrome was considered a contraindication to liver transplantation because the hypoxaemia was likely to increase the perioperative risk and was regarded as essentially irreversible. In fact, as early as 1968 Starzl et al reported the resolution of hypoxaemia in three children after successful transplantation, ${ }^{5}$ and more recently there have been occasional reports in adults. ${ }^{617}$ The published experience of 
transplantation in children with hepatopulmonary syndrome is conflicting. Itasaka et al reported a 13 year old boy transplanted for idiopathic cirrhosis with cyanosis who showed eventual resolution of the cyanosis, though there was a transient increase in the percentage shunt in the postoperative period. ${ }^{7}$ Laberge et al described complete resolution of severe hypoxaemia after transplantation in two children with biliary atresia, and emphasised the importance of proceeding with transplantation early after the onset of cyanosis, even though liver function may be fairly well preserved. ${ }^{8}$ These two children did not have the biliary atresia/polysplenia syndrome. In contrast, Mews et al describe a 12 year old boy with Wilson's disease, cirrhosis and severe hypoxaemia (50\% shunt) who died 10 days after transplantation with persistent hypoxaemia. ${ }^{18}$ It is not clear from this report whether his deterioration occurred despite good graft function.

Our experience shows that the hepatopulmonary syndrome, even when severe, is fully reversible after successful liver transplantation. Two of our patients required prolonged ventilation postoperatively: one, who had the most severe hypoxaemia preoperatively, showed an apparent increase in shunting postoperatively, but had in fact deteriorated since the last preoperative measurement which had been made one month before transplantation. He subsequently made a full recovery. In the second child the difficulty in weaning her from the ventilator was attributed to phrenic nerve weakness and abdominal distention. It has been suggested that a transient increase in shunting might be expected postoperatively due to changes in circulating vasoactive substances which affect normal before abnormal vessels, and to redistribution of blood flow with improved perfusion of the lung bases. ${ }^{7}$

The correlation between liver function, as assessed clinically and biochemically, and the degree of intrapulmonary shunting is not close. ${ }^{14}$ This was the case in our patients, in whom cyanosis was often the main reason for referral for transplantation; liver function was usually stable and not greatly deranged at the time. One child was initially referred for combined liver, heart, and lung transplantation as she was thought to have irreversible pulmonary vascular disease. In the postoperative period there was no correlation between hypoxaemia and minor degrees of liver dysfunction associated with hepatitis or acute rejection. In patient 8, however, in whom there was progressive graft failure with chronic rejection, cyanosis recurred.

The fact that intrapulmonary shunting is reversible after successful liver transplantation, and may recur with graft failure, favours a functional vasodilation of existing vessels as the underlying mechanism, rather than the formation of new vascular channels. Indeed, the invariable association of intrapulmonary shunting with hyperdynamic circulation, clubbing, and often spider naevi, all of which may also reverse after successful transplantation, suggests that it is related to the general vasodilatation seen as an early event in cirrhosis $^{19}$ and thought to result either from excess of an endogenous vasodilator or from the deficiency of a vasoconstrictor. ${ }^{9}$

Numerous substances have been suggested and it is possible that more than one is involved. Attempts to treat the hepatopulmonary syndrome with oestrogens, $\beta$ blockers, ${ }^{20}$ and using plasma exchange have been unsuccessful, ${ }^{9}$ but there are single reports of improvement after the administration of indomethacin $^{21}$ and the somatostatin analogue, octreotide. 9 The substance attracting most attention at present as the possible mediator of vasodilatation in cirrhosis is nitric oxide. There is evidence in rats that inhibitors of nitric oxide synthesis increase the mean arterial pressure in cirrhotic animals, and that this effect can be blocked by pretreatment with the nitric oxide analogue, L-arginine. ${ }^{22}$ Nitric oxide is synthesised locally by vascular endothelial cells and normally has an extremely short half life. There is a form of the enzyme, nitric oxide synthase, however, which can be induced by endotoxin, resulting in a sustained release of nitric oxide. It has been postulated that the chronic endotoxinaemia seen in cirrhotic patients induces this enzyme, leading to a continuous local production of nitric oxide with vasodilatation. ${ }^{23}$

It is unclear why some patients develop the syndrome and others do not. There does not seem to be a close correlation in adults between the aetiology of cirrhosis and the occurrence of the syndrome. Reports in children are limited, but cyanosis has been described with cirrhosis of idiopathic origin, ${ }^{24}$ secondary to biliary atresia, after hepatitis, ${ }^{25}$ and in a child with a primary hepatic tumour. ${ }^{5}$ There are no reported cases of cirrhosis and hepatopulmonary syndrome in children with the combination of biliary atresia, abdominal situs inversus, polysplenia, and abnormalities of the inferior vena cava. This association seems to represent a distinct syndrome, and it is possible that these children have either an increase in potential arteriovenous communications which remain closed when liver function is good, or that their vessels are particularly sensitive to vasodilators. Certainly in the Addenbrooke's series of 173 paediatric liver transplantation patients, no other child has had significant cyanosis. The only child with biliary atresia/polysplenia who was free from cyanosis at the time of transplantation was the youngest ( 6 months old) and had fairly well preserved liver function without the hyperdynamic circulation seen in the other patients.

The technical aspects of an operation in these patients also merit consideration. Their complicated anatomy and previous operations make transplantation more difficult than usual. This was particularly the case in patients 1 and 7 , who weighed less than $8 \mathrm{~kg}$ at the time of operation. In children with an absent or interrupted inferior vena cava the donor hepatic veins were anastomosed directly to the right 
atrium. Blood losses were high, and this was not felt to be solely due to their complicated anatomy and small size; these children seemed to have particularly vascular tissues, perhaps due to their hyperdynamic state and the presence of cutaneous shunts. Despite this no significant intraoperative complications were seen and, in particular, severe hypoxaemia did not occur.

In summary, the children described appeared to have a distinct syndrome of biliary atresia with abdominal situs inversus, polysplenia, and abdominal vascular anomalies, in which intrapulmonary shunting developed rapidly and progressively in step with the vasodilation related to cirrhosis. The cyanosis was completely reversible after successful liver transplantation but recovery was prolonged in the more severe cases. The technical problems of the operation were overcome in experienced hands and good survival was achieved. We therefore suggest that the hepatopulmonary syndrome is not a contraindication to orthotopic liver transplantation in children and that transplantation should be considered as soon as cyanosis occurs.

1 Fluckiger $\mathbf{M}$. Vorkommen von trommelschagelformigen Fingerendphalangen ohne chronische Veranderungen an den lungen oder am Herzen. Wien Med Wochenschr 1884 34: 1457 .

Schomerus H, Buchta I, Arndt H. Pulmonary function studies and oxygen transfer in patients with liver cirrhosis and different degree of portasystemic encephalopathy. Respiration 1975; 32: 1 .

3 Stanley NN, Woodgate DJ. Mottled chest radiograph and gas transfer defect in chronic liver disease. Thorax 1972; 27: 315 .

4 Van Thiel DH, Schade RR, Gavaler JS, et al. Medical aspects of liver transplantation. Hepatology 1984; 4: 79S-83S.

5 Starzl TE, Groth CG, Brettschneider L, et al. Extended survival in 3 cases of orthotopic homotransplantation of the human liver. Surgery 1968; 63: 549-63.

6 Stoller JK, Moodie D, Schiavone WA, et al. Reduction of intrapulmonary shunt and resolution of digital clubbing associated with primary biliary cirrhosis after liver transplantation. Hepatology 1990; 11: 54-8.

7 Itasaka H, Hershon JJ, Cox KL, et al. Transient deterioration of intrapulmonary shunting after pediatric liver transplantation. Transplantation 1993; 55: 212-4.
8 Laberge J-M, Brandt ML, Lebecque P, et al. Reversal of cirrhosis-related pulmonary shunting in two children by orthotopic liver transplantation. Transplantation 1992; 53: orthotopic $1135-8$.

9 Krowka MJ, Cortese DA. Hepatopulmonary syndrome: an evolving perspective in the era of liver transplantation. evolving perspective in the
Hepatology 1990; 11: $138-42$.

10 Snell AM. The effects of chronic disease of the liver on the composition and physicochemical properties of blood: changes in the serum proteins: reduction in oxygen saturation of arterial blood. Ann Intern Med 1935; 9: 690-711.

11 Shaldon S, Caesar J, Chiandussi L, et al. The demonstration of porta-pulmonary anastomoses in portal cirrhosis with the use of radioactive krypton $\left(\mathrm{Kr}^{85}\right)$. N Engl f Med 1961; 265: $410-8$.

12 Berthelot P, Walker JG, Sherlock S, et al. Arterial changes in the lungs in cirrhosis of the liver-lung spider nevi. $N$ Engl the lungs in cirrhosis of the

13 Genovesi MG, Tierney DF, Taplin GV, et al. An intravenous radionuclide method to evaluate hypoxemi caused by abnormal alveolar vessels. Limitation of conventional techniques. Am Rev Respir Dis 1976; 114 59-65.

14 Krowka MJ, Cortese DA. Severe hypoxemia associated with liver disease: Mayo Clinic experience and the experimental use of almitrine bismesylate. Mayo Clin Proc 1987; 62: $164-73$.

15 Sang Oh K, Bender TM, Bowen A, et al. Plain radiographic nuclear medicine and angiographic observations of nuclear medicine and angiographic observations of hepatogenic pulmo

16 Wolfe JD, Tashkin DP, Holly FE, et al. Hypoxemia of cirrhosis. Detection of abnormal small pulmonary vascular channels by a quantitative radionuclide method. Am f Med 1977; 63: 746-53.

17 Eriksson L, Soderman C, Ericzon B, et al. Normalization of ventilation/perfusion relationship after liver transplantation in patients with decompensated cirrhosis: evidence for a hepatopulmonary syndrome. Hepatology 1990; 12: 1350 .

18 Mews F, Dorney SF, Sheil AG, et al. Failure of liver transplantation in Wilson's disease with pulmonary arteriovenous shunting. I Pediatr Gastroenterol Nutr 1990; 10 230-3.

19 Colombato LA, Albillos A, Groszmann RJ. Temporal relationship of peripheral vasodilatation, plasma volum expansion and the hyperdynamic circulatory state in portal-hypertensive rats. Hepatology 1992; 15: 323-8.

20 Sherlock S. Disorders of the liver and biliary system. 8th Ed. Oxford: Blackwell Scientific, 1989: 82-5.

21 Shijo H, Sasaki H, Yuh K, et al. Effects of indomethacin on hepatogenic pulmonary angiodysplasia. Chest 1991; 99: $1027-9$.

22 Claria J, Jimenez W, Ros J, et al. Pathogenesis of arteria hypotension in cirrhotic rats with ascites: role of endogenous nitric oxide. Hepatology 1992; 15: 343-9.

23 Vallance P, Moncada S. Hyperdynamic circulation in cirrhosis: a role for nitric oxide? Lancet 1991; 337: 776-8.

24 Hansoti RC, Sharma S. Cirrhosis of the liver simulatin congenital cyanotic heart disease. Chest 1989; 96: 843-8.

25 Silverman A, Cooper MD, Moller JH, et al. Syndrome of cyanosis, digital clubbing, and hepatic disease in siblings. f Pediatr 1968; 72: 70-80. 